\title{
The oligopeptide transporter hPepT1: gateway to the innate immune response
}

\author{
Laetitia Charrier and Didier Merlin
}

Department of Medicine, Division of Digestive Diseases, Emory University School of Medicine, Atlanta, GA, USA

\begin{abstract}
Bacterial products that are normally present in the lumen of the colon, such as $N$-formylated peptides and muramyl-dipeptide, are important for inducing the development of mucosal inflammation. The intestinal dipeptide transporter, hPepT1, which is expressed in inflamed but not in noninflamed colonic epithelial cells, mediates the transport of these bacterial products into the cytosol of colonic epithelial cells. The small bacterial peptides subsequently induce an inflammatory response, including the induction of MHC class I molecules expression and cytokines secretion, via the activation of nucleotide-binding site and leucine-rich repeat (NBSLRR) proteins, for example NOD2, and activation of NF- $\kappa$ B. Subsequent secretion of chemoattractants by colonic epithelial cells induces the movement of neutrophils through the underlying matrix, as well as across the epithelium. These bacterial products can also reach the lamina propria through the paracellular pathway and across the basolateral membrane of epithelial cells. As a consequence, small formylated peptides can interact directly with immune cells through specific membrane receptors. Since immune cells, including macrophages, also express hPepT1, they can transport small bacterial peptides into the cytosol where these may interact with the NBS-LRR family of intracellular receptors. As in intestinal epithelial cells, the presence of these small bacterial peptides in immune cells may trigger immune response activation.
\end{abstract}

Laboratory Investigation (2006) 86, 538-546. doi:10.1038/labinvest.3700423; published online 1 May 2006

Keywords: hPepT1; bacterial peptides; epithelial cells; immune cells; inflammatory bowel disease

Intestinal inflammation is characterized histologically by epithelial disruption, leading to loss of barrier function, and recruitment of immune cells, especially neutrophils (PMNs), which adhere to and migrate across intestinal epithelia. Although incompletely understood, aberrant interactions between environmental and immunological factors are thought to be critical to the initiation of intestinal inflammation. For example, normal, nonpathogenic bacterial flora plays a key role in the development of intestinal inflammation. ${ }^{1-5}$ Bacteria, including Escherichia coli, release chemotactic substances, such as the $\mathrm{N}$-formylated tripeptide $\mathrm{N}$-formylmethionylleucyl-phenylalanine (fMLP), which specifically interact with and recruit immune cells, especially neutrophils, to sites of inflammation. ${ }^{6,7}$ fMLP is the major $N$-formylated peptide of the human colonic lumen, ${ }^{7,8}$ and the total amount of $N$-formylated peptide in the human colon can reach $10^{-7} \mathrm{M}^{8}$

Correspondence: Dr D Merlin, PhD, Department of Medicine, Division of Digestive Diseases, Emory University School of Medicine, 615 Michael Street, Atlanta, GA 30322, USA.

E-mail: dmerlin@emory.edu

Received 11 March 2006; revised and accepted 16 March 2006; published online 1 May 2006 a concentration that maximally stimulates PMN migration in vitro. ${ }^{9}$ The concentrations of $N$-formyl peptides in the small intestine are lower than those in the colon, ${ }^{7,8,10}$ in parallel with the lower numbers of prokaryotes. Other bacterial dipeptides in the colonic lumen include muramyl-dipeptide (MDP, Ac-muramyl-Ala-Glu), which is present at micromolar concentrations ${ }^{10}$ and was recently identified as a specific activating ligand of the intracellular (nucleotide-binding site and leucine-rich repeat) NBS-LRR family protein, NOD2/CARD15. ${ }^{10-12}$ It is unclear, however, how di- and tripeptides such as fMLP and MDP gain access to the intracellular compartment of the epithelial cells and/or immune system cells located within the lamina propria.

\section{Structure of hPepT1}

One normal transport function of gut epithelial cells is the absorption of small peptides from the diet via an apical membrane peptide transporter. The apical membrane protein that mediates this peptide transport activity, ${ }^{13}$ human PepT1 (hPepT1) cotransports peptides with $\mathrm{H}^{+14}$ and has a broad specificity that includes many di- and tripeptides as well as peptide-derived drugs. ${ }^{15-20}$ Functional expression of 
hPepT1 in Xenopus laevis oocytes induces $\mathrm{H}^{+}$dependent peptide transport activity, thus recapitulating the peptide transporting activity observed in natural gut epithelia. ${ }^{13,21}$ The hPepT1 protein expressed in polarized intestinal epithelial cells, which have an acidic microclimate, functions optimally at lower extracellular $\mathrm{pH}$. hPepT1 is appropriately expressed on the apical membrane of the human gut epithelial cell line, Caco $2,{ }^{22,23}$ which can be used as an in vitro model for biological analyses of this transporter. The cDNA encoding this human oligopeptide transporter is 2263 base pairs (bp) long, with an open reading frame of $2127 \mathrm{bp}$ and encodes a 708 amino-acid protein with a predicted molecular size of $78 \mathrm{kDa} .{ }^{13}$ The hydropathy plot of hPepT1 suggests there are 12 putative membranespanning domains. ${ }^{13,18}$ In vivo and in vitro studies have shown that hPepT1 transports di- and tripeptides, but not free amino acids or peptides with more than three amino-acid residues. ${ }^{15-20}$ These peptide substrates vary greatly in net charge, solubility, and molecular weights, from 96.2 Da (di-Gly) to $522.6 \mathrm{Da}$ (tri-Trp) and include the bacterial tri-peptide fMLP. ${ }^{9}$

\section{hPepT1 is expressed in normal small intestine but not in normal colon}

PepT1 is primarily expressed in brush border membranes of enterocytes in the small intestine, in proximal tubular cells of the S1 segment of the kidney, and in bile duct epithelial cells. ${ }^{16,17,24-30}$ Within the small intestine, PepT1 has a differential pattern of expression. Along the vertical axis, PepT1 is most abundant at the villous tip and expression decreases towards the crypt. ${ }^{25,31,32}$ Along the longitudinal axis, the density of PepT1 increases from duodenum to ileum. ${ }^{33}$ Expression of PepT1 mRNA or protein is marginal ${ }^{34}$ or not detected ${ }^{25,30,35}$ in the colon, but is transiently expressed in normal rat colon during the first few days after birth. ${ }^{36}$ Under these conditions, there is little PepT1-mediated transport of bacterial products, including fMLP and MDP. Although hPepT1 is expressed in the small intestine-like cell line Caco2-BBE but not in the colonic-like cell line HT29-Cl.19A. ${ }^{35}$

\section{Intestinal epithelial hPepT1 transports the bacterial di- and tripeptides MDP and fMLP}

fMLP and MDP are transported across the apical plasma membrane of Caco2-BBE cells. ${ }^{9,10}$ fMLP is also transported into Xenopus oocytes expressing hPepT1, and fMLP transport in Caco2-BBE cells and Xenopus oocytes is competitively inhibited by known hPepT1 dipeptide substrates, but not by free amino acids. ${ }^{9}$ There is little terminal hydrolysis of a variety of oligopeptides at the brush border, with about $90 \%$ of each transported into the cytosol as intact di- or tripeptides. ${ }^{15}$ fMLP exit across the basolateral membranes is mediated by a distinct transport system which is likely the rate-limiting step in transcellular transport. ${ }^{9}$ Therefore, intestinal epithelial cells expressing hPepT1 may accumulate significant quantities of bacterial peptides in the cytosol if these peptides are present at significant concentrations in the lumen.

\section{$\mathrm{hPepT} 1$ expression is induced in colonic epithelial cells during inflammation}

Although PepT1 is not normally expressed in colonic epithelial cells, ${ }^{25,34,35}$ we detected hPepT1 expression in epithelial cells of chronically inflamed colon. ${ }^{35}$ Immunohistochemical experiments showed that hPepT1 protein was expressed in colon from patients with ulcerative colitis or Crohn's disease (Merlin et al; ${ }^{35}$ Figure 1). As in normal small intestine epithelial cells, expression was primarily at the apical membrane of colonic epithelial cells (Merlin et $a l ;{ }^{35}$ Figure 1), suggesting that hPepT1 expression can be induced in colonic cells under inflammatory conditions. Expression of hPepT1 has also been found to be up-regulated in the colonic mucosa of patients with short-bowel syndrome following surgical resection of the proximal small intestine, again indicating that hPepT1 expression is induced in colonic epithelial cells under pathological conditions. ${ }^{34}$ The finding that hPepT1 mRNA and protein expression is induced in colonic epithelial cells under inflammatory conditions suggests that specific transcriptional regulation by signaling pathway(s) may be activated. Furthermore, these observations suggest that inflamed, but not noninflamed, colonic epithelial cells may be able to transport bacterial products such as fMLP and MDP, which are present in the colonic lumen..$^{7,8,10}$

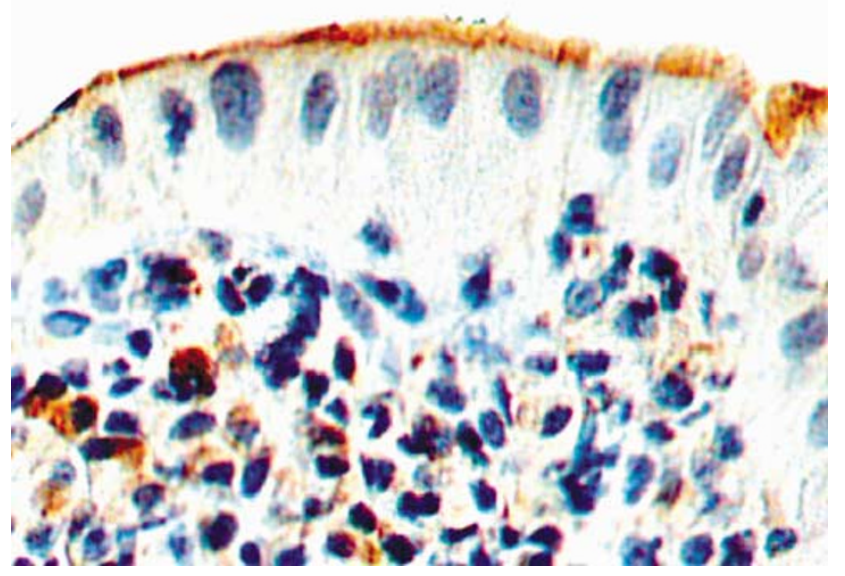

Figure 1 Chronic colitis is associated with hPepT1 expression in human colon. Frozen sections of mucosa of chronic ulcerative colitis (chronic active colitis) were stained with anti-hPepT1 antibody. Sections were counterstained for nuclei with methyl green. hPepT1 staining was localized to the apical membrane of colonic epithelial cells. ${ }^{35}$ In addition, hPepT1 staining was also detected in the immune cells present in the lamina propria. 


\section{Colonic hPepT1 expression during inflammation is regulated by cytokines}

PepT1 expression is precisely regulated at the protein level. For example, interferon- $\gamma$ (IFN $\gamma$ ), which is present at high levels in inflammatory bowel disease (IBD) tissues, causes a phenotypic shift in enterocytes, preparing them for a role in host defense. ${ }^{37-40}$ We and others have found that IFN $\gamma$ increases hPepT1-mediated uptake of di- and tripeptides, including fMLP, by Caco2-BBE cells, without affecting hPepT1 mRNA content. ${ }^{41,42}$ Low concentrations of IFN $\gamma$ have been found to increase intracellular $\mathrm{pH}$, enhancing the $\mathrm{H}^{+}$electrochemical gradient across the apical plasma membrane in Caco2-BBE monolayers, ${ }^{42}$ which, in turn, is responsible for the increase in hPepT1-mediated transport events. ${ }^{14}$ Other in vivo and in vitro studies have demonstrated that the short-term effects of leptin, as well as high concentrations of IFN $\gamma$ and tumor necrosis factor $\alpha(\mathrm{TNF} \alpha)$ that stimulate dipeptide transport, result from increased trafficking of PepT1 from intracellular pools to the apical membrane. ${ }^{42,43}$

Interestingly, another cytokine, interleukin-1 $\beta$ (IL$1 \beta$ ), has been shown to increase the amounts of PepT1 mRNA and protein in the murine proximal and distal colon without increasing the functional activity of PepT1. ${ }^{43}$ This suggests that IL- $\beta$-induced PepT1 is not expressed on the cell surface, but is retained in an intracellular compartment. ${ }^{42}$ Under inflammatory conditions, hPepT1 expression in colonic epithelial cells is likely induced at the transcriptional level, since little or no hPepT1 expression is observed in noninflammatory colonic epithelial cells. ${ }^{34,35}$ Consistent with this, recent cloning of the $5^{\prime}$-flanking region of the hPepT1 gene identified several GC-rich sites that may bind the transcription factor Sp1, suggesting that Sp1 may function as a basal transcriptional regulator of the $h P e p T 1$ gene. ${ }^{44}$ This work also identified additional cis elements and trans factors involved in the regulation of hPepT1 transcription, which may relate to the upregulation of dipeptide transport activity as a result of PepT1 gene transcriptional activation by specific dietary amino acids and dipeptides in rats ${ }^{45}$ and by media supplementation in Caco2 cells. ${ }^{46,47}$ Thus, one might hypothesize that bacterial peptides increase PepT1 in transcriptional activation and that the resulting epithelial PepT1 expression perpetuates intestinal inflammation. This mechanism, however, is not likely to be responsible for the initiation of PepT1 expression in colonic epithelium. We recently demonstrated that long-term treatment of Caco2-BBE cells with leptin, a proinflammatory cytokine involved in IBD, ${ }^{48}$ increases hPepT1 expression and activity via activation of its promoter. ${ }^{49}$ We also observed that inflamed human colonic epithelial cells of individuals with ulcerative colitis secrete leptin into the intestinal lumen, similar to that observed in vitro by IFN $\gamma$-treated Caco2-BBE cells. ${ }^{48}$ Therefore, upregulation of hPepT1 activity by leptin may be directly related to IBD pathogenesis.

\section{PepT1-mediated fMLP transport induces intestinal inflammation in vitro and in vivo}

fMLP is a neutrophil chemoattractant, an activity mediated through the interactions of fMLP with specific G protein-coupled receptors on neutrophil plasma membranes. ${ }^{6,7}$ This, in turn, leads to the transepithelial migration of stimulated neutrophils. It was originally thought that this recruitment of neutrophils was induced by a paracellular gradient of fMLP created by its passive diffusion across tight junctions and into paracellular spaces. However, the discovery of hPepT1-mediated transport of fMLP provides new perspectives for mechanisms by which fMLP could reach neutrophils. For example, transcellular oligopeptides transport via apical hPepT1 and a separate basolateral di/tripeptide transporter ${ }^{9,22,50,51}$ allows fMLP to be released into the lamina propria, where it can interact with neutrophils and activate transepithelial migration. In addition, the intracellular accumulation of $\mathrm{N}$ formyl peptides may biologically influence the interactions of neutrophils with epithelial monolayers. For example, in Caco2-BBE cells, inhibition of hPepT1-mediated uptake of fMLP attenuates the fMLP-driven transepithelial migration of neutrophils by $50 \% .^{9}$ Conversely, enhancing hPepT1mediated epithelial absorption of fMLP increases the transepithelial migration of neutrophils. ${ }^{9}$ The most straightforward interpretation of these observations is that active transepithelial transport of fMLP favorably modifies the transepithelial gradient of the chemoattractant, leading to a more efficient movement of neutrophils across epithelial cells. However, some data also suggest that intracellular uptake of $\mathrm{N}$ formyl peptides may trigger rapid signals that lead to modifications of the basolateral membranes with which neutrophils interact during transepithelial migration. ${ }^{52}$ In vivo analysis in rat jejunum showed initial evidence of inflammation within $4 \mathrm{~h}$ of perfusion with $10 \mu \mathrm{M}$ fMLP, including epithelial exfoliation, blunted and broadened villi, interstitial edema, vessel dilation, and increased numbers of inflammatory cells (lymphocytes and polynuclear cells) in the lamina propria. ${ }^{52}$ By contrast, the colon showed no evidence of fMLP-induced inflammation, ${ }^{52}$ consistent with the observation that PepT1 is expressed in the small intestine but not in the colon of rats ${ }^{25}$ and humans. ${ }^{35}$ Moreover, the ability of $50 \mathrm{mM}$ Gly-Gly to completely inhibit fMLP-induced inflammation in the jejunum confirms the critical role of PepT1 in this model. Thus, colonocytes, which are exposed to high levels of luminal fMLP, ${ }^{7}$ are insensitive to fMLP, while small intestinal enterocytes can respond to fMLP but are normally exposed to only low luminal concentrations, consistent with lower bacterial load. Thus, some disease 
Table 1 Correlation in the presence of the major players of PepT1-mediated intestinal inflammation

\begin{tabular}{|c|c|c|c|c|c|}
\hline & $\begin{array}{l}\text { PepT1 } \\
\text { activity }\end{array}$ & $\begin{array}{l}\text { NOD2 } \\
\text { expression }\end{array}$ & $\begin{array}{l}\text { Normal small } \\
\text { intestine }\end{array}$ & Normal colon & Inflamed colon \\
\hline $\mathrm{IFN} \gamma$ & Increased $^{41,42}$ & Increased $^{87}$ & $\begin{array}{l}\text { Low } \\
\text { concentration }\end{array}$ & $\begin{array}{l}\text { Low } \\
\text { concentration } \\
37-40\end{array}$ & $\begin{array}{l}\text { High } \\
\text { concentration } \\
37-40\end{array}$ \\
\hline $\mathrm{TNF} \alpha$ & Increased $^{42}$ & Increased $^{85,87}$ & $\begin{array}{l}\text { Low } \\
\text { concentration } \\
113,114\end{array}$ & $\begin{array}{l}\text { Low } \\
\text { concentration } \\
113,114\end{array}$ & $\begin{array}{l}\text { High } \\
\text { concentration }^{113,114}\end{array}$ \\
\hline Leptin & Increased $^{43,49}$ & $?$ & $\begin{array}{l}\text { Low } \\
\text { concentration }{ }^{48}\end{array}$ & $\begin{array}{l}\text { Low } \\
\text { concentration }^{48}\end{array}$ & $\begin{array}{l}\text { High } \\
\text { concentration }^{48}\end{array}$ \\
\hline PepT1 & - & - & $\begin{array}{l}\text { High } \\
\text { expression }{ }^{25,26,29,35}\end{array}$ & $\begin{array}{l}\text { Low } \\
\text { expression }{ }^{25,30,34,35}\end{array}$ & Expression $^{25,35}$ \\
\hline $\begin{array}{l}\text { Bacterial di/tripeptides } \\
\text { (fMLP, MDP) }\end{array}$ & - & - & Not abundant ${ }^{8,10}$ & Abundant ${ }^{8,10}$ & Abundant ${ }^{8,10}$ \\
\hline NOD2 & - & - & Expressed $^{65-67}$ & Expressed $^{65-67}$ & Expressed $^{65-67}$ \\
\hline
\end{tabular}

states, such as bacterial overgrowth, may allow small intestinal fMLP concentrations to induce PepT1-mediated inflammation while in the colon, expression of hPepT1 in chronic colitis ${ }^{35}$ may allow hPepT1-mediated transport to sustain the inflammatory process (Table 1).

\section{Intracellular accumulation of bacterial products such as fMLP and MDP leads to the activation of inflammatory responses by intestinal epithelial cells}

Intracellular accumulation of bacterial products such as fMLP and MDP may trigger intracellular signals that lead to the initiation of intestinal inflammatory responses. ${ }^{35}$ For example, we found that uptake of fMLP by colonic epithelial cells led to the induction of MHC class I molecules expression. ${ }^{35}$ This effect is specific for $N$-formylated peptides, since Gly-Leu did not alter MHC class I expression, and is mediated through hPepT1 transport, since increased MHC class I expression was observed in HT29-Cl.19A cells engineered to express hPepT1 (HT29-Cl.19A/hPepT1) but not in HT29-Cl.19A cells without hPepT1 expression (HT29-Cl.19A/GFP).$^{35}$ It is tempting to hypothesize that these newly synthesized MHC class I molecules can be used for antigenic presentation of bacterial products, including fMLP, especially since, in mice, MHC class I molecules including H-2M3a are able to present fMLP on the cell surface. ${ }^{53-60}$ Upon induction of hPepT1 expression, colonic epithelial cells would then be able to act as sensors for the presence of bacteria, signaling 'bacterial invasion' to immune cells, which can then eliminate the bacteria. Transport of fMLP in Caco2-BBE cells has been found to stimulate NF- $\kappa \mathrm{B}$ and AP-1 activities, which may lead to the activation of inflammatory responses by intestinal epithelial cells. ${ }^{52}$ In addition, MDP induces NF- $\kappa$ B activation in Caco2-BBE cells, as observed by its nuclear translocation and by the secretion of the chemokines IL-8 and monocyte chemoattractant protein-1 (MCP-1). ${ }^{10}$ The MDP- induced IL-8 secretion could be abolished by either NOD2 or hPepT1 siRNA, ${ }^{10}$ suggesting that intracellular accumulation of MDP is mediated by hPepT1 and that the MDP/NOD2 interaction induces IL-8 secretion by intestinal epithelial cells. ${ }^{10-12}$ Interestingly, mucosal IL-8 and MCP-1 are highly expressed in regions of active IBD (for a review, see MacDermott $\left.{ }^{61}\right)$. As IL-8 and MCP-1 are chemoattractants for neutrophils and monocytes, respectively, ${ }^{62}$ the finding that hPepT1-mediated transport of bacterial oligopeptides into intestinal epithelial cells stimulates IL-8 secretion ${ }^{10}$ and increases neutrophil transepithelial migration ${ }^{9}$ indicates that hPepT1mediated transport of luminal bacterial products into intestinal epithelial cells induces a cascade of signaling events. Among these signals, NF- $\kappa \mathrm{B}$ is activated through the binding of the transported bacterial oligopeptide to NOD2. Once activated, NF$\kappa \mathrm{B}$ can then stimulate expression and secretion of cytokines, including IL-8 and MIP-1, which may subsequently interact with and recruit immune cells.

\section{hPepT1 expression by immune cells}

Immune cells, such as macrophages, are in close contact with the lamina propria of the small intestine, ${ }^{63,64}$ where low concentrations of small bacterial-derived peptides are present. Under normal conditions, this constant low concentration of fMLP activates a physiological baseline level of inflammation. ${ }^{65,66}$ During inflammation, however, colonic tissues express PepT1 (Merlin et $a 3^{35}$ and Buyse et $a{ }^{41}$ Figure 1), which participates in the active transport of fMLP from the lumen to the lamina propria where immune cells are located and would be expected to participate in immune cell activation. However, as macrophages expressing triggering receptor expressed on myeloid cells-1 (TREM-1), a receptor involved in inflammatory responses, are underrepresented in the human intestine ${ }^{67}$ other receptor(s) must be involved in macrophage activation. Interestingly, we noted that, 
within the lamina propria of inflamed colonic tissues, some cells stain positively for hPepT1 (Figure 1). To further investigate hPepT1 expression by human immune cells we assessed hPepT1 expression in cell lysates from human peripheral blood mononuclear cells and macrophages and the human monocytic cell line KG-1. ${ }^{68}$ We also cloned hPepT1 cDNA from KG-1 cells (Y Yan and D Merlin, GenBank Accession No. AY634368) and found that it was $100 \%$ homologous to the published coding sequence of hPepT1 in Caco2 cells (GenBank accession No. AF043233). This hPepT1 expressed on human macrophages appears to be functional, since it mediates the transport of di- and tripeptides, including fMLP. ${ }^{68}$ Interestingly, the optimal activity of hPepT1 was seen at $\mathrm{pH} \mathrm{7.2,} \mathrm{the} \mathrm{pH}$ of the immune cell environment. These results suggest that bacterial di- and tripeptides such as MDP and fMLP may be taken up by the immune cells that reside in the lamina propria of the intestine.

\section{Potential role of by $\mathrm{hPepT1-mediated}$ transport of fMLP/MDP in immune cell activation}

Induction of an immune response requires recognition of microorganisms by host receptors, such as fMLP receptors or toll-like receptors (TLRs), expressed on immune system cells. ${ }^{66,69-72}$ Alternative receptors from the family of the NBS-LRR proteins, such as NOD2, are also able to detect specific bacterial compounds, such as MDP, and induce inflammatory responses. ${ }^{65,73-79}$ Dysregulation of this recognition event due to mutations in genes encoding these receptors is involved in numerous autoinflammatory disorders, ${ }^{65}$ including Crohn's disease. ${ }^{65,80-84}$ Expression of hPepT1 by antigen presenting cells may therefore have important physiological relevance. For example, bacterial peptides such as fMLP or MDP, which are transported by hPepT1,,$^{9,10,35}$ could be taken up by

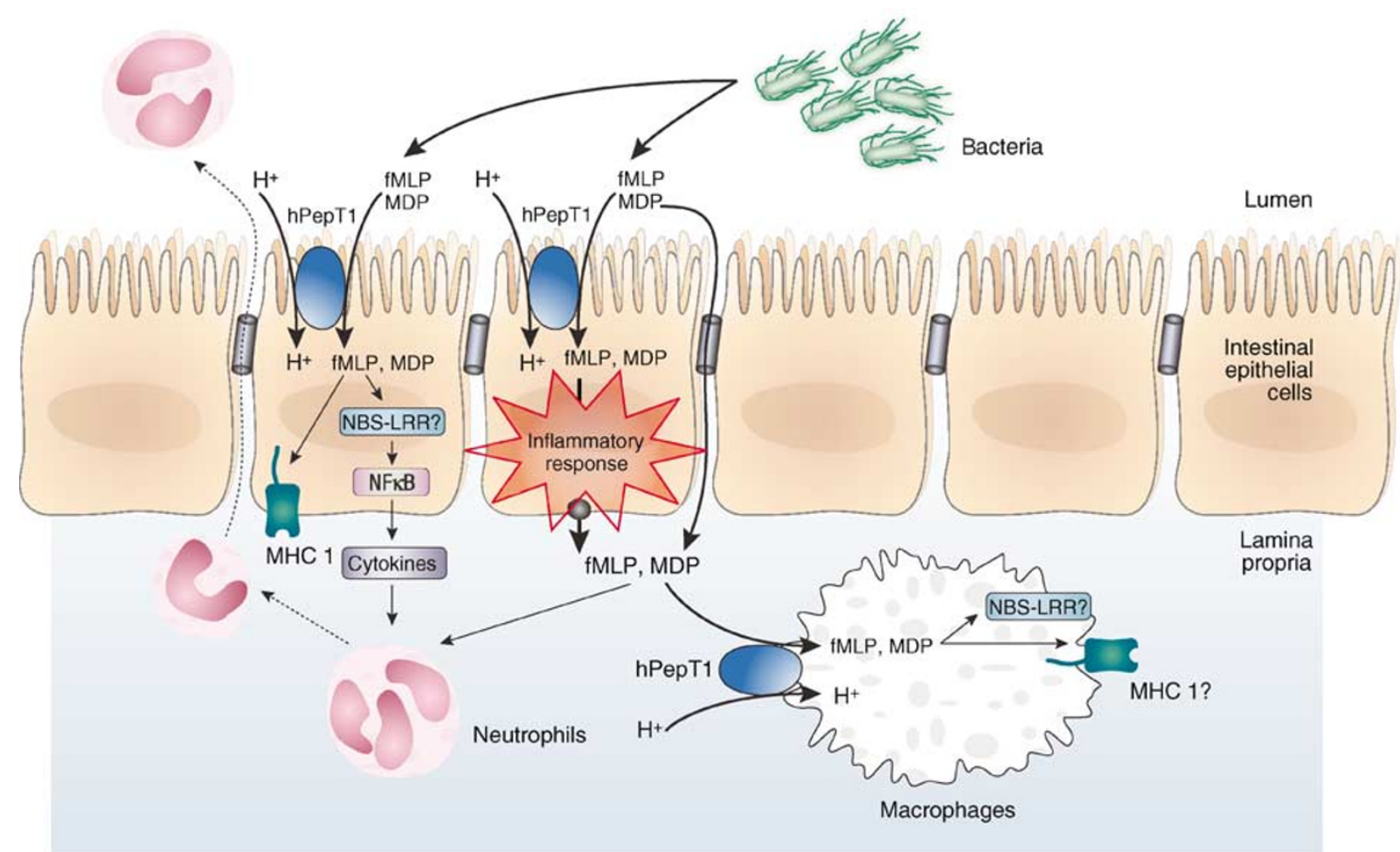

Figure 2 Summary/model of involvement of hPepT1 in IBD. This figure depicts a model for the involvement of hPepT1 in IBD, based on the literature reviewed here. Bacterial products, such as fMLP and MDP, are normally present in the intestinal lumen. Intestinal hPepT1, which is expressed in inflamed but not in noninflamed colonic epithelial cells, mediates the transport of these bacterial products into the cytosol. The uptake into the cytosol of these small bacterial peptides then induces an inflammatory response at the level of the intestinal epithelial cell. This response includes the induction of MHC I expression and cytokine secretion via the activation of NBS-LRR proteins (eg NOD2) and the subsequent activation of NF- $\kappa$ B. Secreted cytokines then recruit immune system cells such as neutrophils to the site of inflammation. In addition, fMLP can interact directly with immune cells. Indeed, fMLP can reach the lamina propria through the paracellular pathway, since tight junctions are permeable to fMLP. This leakage of fMLP will be enhanced in patients with IBD, since the intestinal epithelial barrier is disrupted. In addition, there may be an efflux of fMLP across the basolateral membrane via a basolateral peptide transporter. ${ }^{9,22,50,51}$ As a consequence, fMLP and other small formylated peptides can bind to specific membrane receptors on immune cells. Since immune cells including macrophages also express PepT1, they can take up small bacterial peptides, which can interact with the NBS-LRR family of intracellular receptors (eg NOD2). As described in intestinal epithelial cells, the presence of these small bacterial peptides in immune system cells may participate in the induction of an immune response, through the NBS-LRR proteins that are involved in intracellular recognition of microbes and their products. ${ }^{65,73-79}$ (Power Point slide series of figure 2 is available online as supplementary information on the Laboratory Investigation website: http//www.nature.com/labinvest.) 
macrophages, which could, in turn, participate in the intestinal mucosal immune response. We propose that, during intestinal inflammation, luminalderived bacterial products, such as fMLP, may be taken up by macrophages present in the lamina propria. These bacterial products may participate in the activation of an immune response by antigen presentation via MHC class I or II molecules, ${ }^{53-60}$ or may be recognized by intracellular receptors such as NOD2 (Figure 2), which is expressed in myeloid cells $^{71,73}$ and upregulated by proinflammatory mediators. ${ }^{85-87}$

\section{Perspectives}

The findings reviewed above regarding the involvement of hPepT1 in IBD open new prospects in the treatment of this disease. It is interesting that this transporter is resistant to intestinal injury encountered in pathological states. Since colonic PepT1 is upregulated during intestinal inflammation, its transport function can be considered a tool in the development of anti-inflammatory therapies. Furthermore, the importance of hPepT1 expression by immune cells during intestinal inflammatory states should be evaluated. Therapeutically, it may be useful to develop anti-inflammatory drugs, the effect of which can be mediated by colonic hPepT1. Examples of drugs and prodrugs that act as substrates for PepT1 include $\beta$-lactam antibiotics, cephalosporins, ACE-inhibitors, L-valine ester prodrugs such as valacyclovir, renin and thrombin inhibitors, bestatin, and the valine ester prodrugs of aciclovir and ganciclovir. ${ }^{88-106}$ It would be interesting to investigate hPepT1-mediated transport of anti-inflammatory di- and tripeptides. For example, the tripeptide KPV was recently shown to have antiinflammatory activities. Although its underlying mechanisms are not known, the ability of KPV to inhibit $N F-\kappa B$ activation suggests that it may act by inhibiting the synthesis of pro-inflammatory cytokines. ${ }^{107-112}$ These peptides may therefore be good candidates for mediators of anti-inflammatory effects, by acting through PepT1 expressed in inflamed colonic epithelial and immune cells.

\section{Acknowledgements}

This work was supported by National Institute of Diabetes and Digestive and Kidney Diseases under center grant R24-DK-064399 and National Institutes of Health grant DK061941 to Dr D Merlin. Dr L Charrier is supported by the Crohn's and Colitis Foundation of America and Elvin and Janet Price.

\section{References}

1 Sadlack B, Merz H, Schorle H, et al. Ulcerative colitislike disease in mice with a disrupted interleukin-2 gene. Cell 1993;75:253-261.
2 Brandwein SL, McCabe RP, Cong Y, et al. Spontaneously colitic $\mathrm{C} 3 \mathrm{H} / \mathrm{HeJBir}$ mice demonstrate selective antibody reactivity to antigens of the enteric bacterial flora. J Immunol 1997;159:44-52.

3 McCormick BA, Colgan SP, Delp-Archer C, et al. Salmonella typhimurium attachment to human intestinal epithelial monolayers: transcellular signalling to subepithelial neutrophils. J Cell Biol 1993;123: 895-907.

4 McCormick BA, Hofman PM, Kim J, et al. Surface attachment of Salmonella typhimurium to intestinal epithelia imprints the subepithelial matrix with gradients chemotactic for neutrophils. J Cell Biol 1995;131:1599-1608.

5 McCormick BA, Parkos CA, Colgan SP, et al. Apical secretion of a pathogen-elicited epithelial chemoattractant activity in response to surface colonization of intestinal epithelia by Salmonella typhimurium. J Immunol 1998;160:455-466.

6 Bommakanti RK, Bokoch GM, Tolley JO, et al. Reconstitution of a physical complex between the $\mathrm{N}$-formyl chemotactic peptide receptor and G protein. Inhibition by pertussis toxin-catalyzed ADP ribosylation. J Biol Chem 1992;267:7576-7581.

7 Marasco WA, Phan SH, Krutzsch H, et al. Purification and identification of formyl-methionyl leucyl-phenylalanine as the major peptide neutrophil chemotactic factor produced by Escherichia coli. J Biol Chem 1984;259:5430-5439.

8 Chadwick VS, Mellor DM, Myers DB, et al. Production of peptides inducing chemotaxis and lysosomal enzyme release in human neutrophils by intestinal bacteria in vitro and in vivo. Scand J Gastroenterol 1988;23:121-128.

9 Merlin D, Steel A, Gewirtz AT, et al. hPepT1mediated epithelial transport of bacteria-derived chemotactic peptides enhances neutrophil-epithelial interactions. J Clin Invest 1998;102:2011-2018.

10 Vavricka SR, Musch MW, Chang JE, et al. hPepT1 transports muramyl dipeptide, activating NF kappaB and stimulating IL-8 secretion in human colonic Caco2/bbe cells. Gastroenterology 2004;127:1401-1409.

11 Girardin SE, Boneca IG, Viala J, et al. Nod2 is a general sensor of peptidoglycan through muramyl dipeptide (MDP) detection. J Biol Chem 2003;278: 8869-8872.

12 Tanabe T, Chamaillard M, Ogura Y, et al. Regulatory regions and critical residues of NOD2 involved in muramyl dipeptide recognition. EMBO J 2004;23: 1587-1597.

13 Liang R, Fei YJ, Prasad PD, et al. Human intestinal $\mathrm{H}+$ /peptide cotransporter. Cloning, functional expression, and chromosomal localization. J Biol Chem 1995;270:6456-6463.

14 Steel A, Nussberger S, Romero MF, et al. Stoichiometry and $\mathrm{pH}$ dependence of the rabbit protondependent oligopeptide transporter PepT1. J Physiol 1997;498:563-569.

15 Adibi SA. The oligopeptide transporter (Pept-1) in human intestine: biology and function. Gastroenterology 1997;113:332-340.

16 Adibi SA. Regulation of expression of the intestinal oligopeptide transporter (Pept-1) in health and disease. Am J Physiol Gastrointest Liver Physiol 2003;285: G779-G788. 
17 Daniel H. Molecular and integrative physiology of intestinal peptide transport. Annu Rev Physiol 2004; 66:361-384.

18 Daniel H, Kottra G. The proton oligopeptide cotransporter family SLC15 in physiology and pharmacology. Pflügers Arch 2004;447:610-618.

19 Fei YJ, Ganapathy V, Leibach FH. Molecular and structural features of the proton coupled oligopeptide transporter superfamily. Prog Nucleic Acid Res Mol Biol 1998;58:239-261.

20 Meredith D, Boyd CAR. Structure and function of eukaryotic peptide transporters. Cell Mol Life Sci 2000;57:754-778.

21 Nussberger S, Steel A, Trotti D, et al. Symmetry of H+ binding to the intra- and extracellular side of the H+-coupled oligopeptide cotransporter PepT1. J Biol Chem 1997;272:7777-7785.

22 Saito H, Inui K-I. Dipeptide transporters in apical and basolateral membranes of the human intestinal cell line Caco2. Am J Physiol 1993;265:G289-G294.

23 Thwaites DT, Hirst BH, Simmons NL. Direct assessment of dipeptide/H+ symport in intact human intestinal (Caco-2) epithelium: a novel method utilising continuous intracellular $\mathrm{pH}$ measurement. Biochem Biophys Res Commun 1993;194:432-438.

24 Knutter I, Rubio-Aliaga I, Boll M, et al. H+ peptide cotransport in the human bile duct epithelium cell line SK-ChA-1. Am J Physiol 2002;283:G222-G229.

25 Ogihara H, Saito H, Shin BC, et al. Immuno-localization of $\mathrm{H}+$ /peptide cotransporter in rat digestive tract. Biochem Biophys Res Commun 1996;220:848-852.

26 Saito $\mathrm{H}$, Okuda $\mathrm{M}$, Terada $\mathrm{T}$, et al. Cloning and characterization of a rat $\mathrm{H}+$ /peptide cotransporter mediating absorption of $\beta$-lactam antibiotics in the intestine and kidney. J Pharmacol Exp Ther 1995; 275:1631-1637.

27 Shen H, Smith DE, Yang T, et al. Localization of PEPT1 and PEPT2 proton-coupled oligopeptide transporter mRNA and protein in rat kidney. Am J Physiol 1999;276:F658-F665.

28 Smith DE, Pavlova A, Berger UV, et al. Tubular localization and tissue distribution of peptide transporters in rat kidney. Pharmaceut Res 1998;15: 1244-1249.

29 Freeman TC, Bentsen BS, Thwaites DT, et al. $\mathrm{H}+/$ di-tripeptide transporter (PepT1) expression in the rabbit intestine. Pflügers Arch 1995;430:394-400.

30 Sai Y, Tamai I, Sumikawa H, et al. Immunolocalization and pharmacological relevance of oligopeptide transporter PepT1 in intestinal absorption of betalactam antibiotics. FEBS Lett 1996;392:25-29.

31 Takahashi K, Nakamura N, Terada T, et al. Interaction of beta-lactam antibiotics with $\mathrm{H}+/$ peptide cotransporters in rat renal brush-border membranes. J Pharmacol Exp Ther 1998;286:1037-1042.

32 Ogihara H, Suzuki T, Nagamachi Y, et al. Peptide transporter in the rat small intestine: ultrastructural localization and the effect of starvation and administration of amino acids. Histochem J 1999;31:169-174.

33 Tanaka H, Miyamoto KI, Morita K, et al. Regulation of the PepT1 peptide transporter in the rat small intestine in response to 5-fluorouracil-induced injury. Gastroenterology 1998;114:714-723.

34 Ziegler TR, Fernandez-Estivariz C, Gu LH, et al. Distribution of the $\mathrm{H}+$ /peptide transporter PepT1 in human intestine: up-regulated expression in the colonic mucosa of patients with short-bowel syndrome. Am J Clin Nutr 2002;75:922-930.

35 Merlin D, Si-Tahar M, Sitaraman SV, et al. Colonic epithelial hPepT1 expression occurs in inflammatory bowel disease: transport of bacterial peptides influences expression of MHC class 1 molecules. Gastroenterology 2001;120:1666-1679.

36 Shen H, Smith DE, Brosius III FC. Developmental expression of PEPT1 and PEPT2 in rat small intestine, colon, and kidney. Pediatr Res 2001;49:789-795.

37 Colgan SP, Parkos CA, Matthews JB, et al. Interferongamma induces a cell surface phenotype switch on T84 intestinal epithelial cells. Am J Physiol 1994; 267:C402-C410.

38 Colgan SP, Morales VM, Madara JL, et al. IFN-gamma modulates CD1d surface expression on intestinal epithelia. Am J Physiol 1996;271:C276-C283.

39 Parkos CA, Colgan SP, Diamond MS, et al. Expression and polarization of intercellular adhesion molecule-1 on human intestinal epithelia: consequences for CD11b/CD18-mediated interactions with neutrophils. Mol Med 1996;2:489-505.

40 Steiniger B, Falk P, Lohmuller M, et al. Class II MHC antigens in the rat digestive system. Normal distribution and induced expression after interferon-gamma treatment in vivo. Immunology 1989;68:507-513.

41 Buyse M, Charrier L, Sitaraman S, et al. Interferongamma increases hPepT1-mediated uptake of ditripeptides including the bacterial tripeptide fMLP in polarized intestinal epithelia. Am J Pathol 2003; 163:1969-1977.

42 Vavricka SR, Musch MW, Fujiya M, et al. Tumor necrosis factor-alpha and interferon-gamma increase PepT1 expression and activity in the human colon carcinoma cell line Caco-2/bbe and in mouse intestine. Pflügers Arch 2005;19:1-10.

43 Buyse M, Berlioz F, Guilmeau S, et al. PepT1mediated epithelial transport of dipeptides and cephalexin is enhanced by luminal leptin in the small intestine. J Clin Invest 2001;108:1483-1494.

44 Shimakura J, Terada T, Katsura T, et al. Characterization of the human peptide transporter PEPT1 promoter: $\mathrm{Sp} 1$ functions as a basal transcriptional regulator of human PEPT1. Am J Physiol Gastrointest Liver Physiol 2005;289:G471-G477.

45 Shiraga T, Miyamoto K, Tanaka H, et al. Cellular and molecular mechanisms of dietary regulation on rat intestinal $\mathrm{H}+$ /peptide transporter PepT1. Gastroenterology 1999;116:354-362.

46 Thamotharan M, Bawani SZ, Zhou X, et al. Mechanism of dipeptide stimulation of its own transport in a human intestinal cell line. Proc Assoc Am Physicians 1998;110:361-368.

47 Walker D, Thwaites DT, Simmons NL, et al. Substrate upregulation of the human small intestinal peptide transporter, hPepT1. J Physiol 1998;507:697-706.

48 Sitaraman S, Liu X, Charrier L, et al. Colonic leptin: source of a novel proinflammatory cytokine involved in IBD. FASEB J 2004;18:696-698.

49 Nduati V, Driss A, Sitaraman S, et al. Transcriptional Regulation of the Human Peptide Transporter PepT1 by Leptin in Intestinal Epithelia. FASEB Meeting, Experimental Biology 2006.

50 Irie M, Terada T, Okuda M, et al. Efflux properties of basolateral peptide transporter in human intestinal cell line Caco-2. Pflügers Arch 2004;449:186-194. 
51 Terada T, Sawada K, Saito $\mathrm{H}$, et al. Functional characteristics of basolateral peptide transporter in the human intestinal cell line Caco-2. Am J Physiol 1999;276:G1435-G1441.

52 Buyse M, Tsocas A, Walker F, et al. PepT1-mediated fMLP transport induces intestinal inflammation in vivo. Am J Physiol Cell Physiol 2002;283:C1795C1800.

53 Chiu NM, Chun T, Fay M, et al. The majority of H2M3 is retained intracellularly in a peptide receptive state and traffics to the cell surface in the presence of $\mathrm{N}$-formylated peptides. J Exp Med 1999;190:423-434.

54 Lindahl KF, Byers DE, Dabhi VM, et al. H2-M3, a fullservice class Ib histocompatibility antigen. Annu Rev Immunol 1997;15:851-879.

55 Shawar SM, Cook RG, Rodgers JR, et al. Specialized functions of MHC class I molecules. I. An $N$-formyl peptide receptor is required for construction of the class I antigen Mta. J Exp Med 1990;171:897-912.

56 Shawar SM, Vyas JM, Rodgers JR, et al. Specialized functions of major histocompatibility complex class I molecules. II. Hmt binds $N$-formylated peptides of mitochondrial and prokaryotic origin. J Exp Med 1991;174:941-944.

57 Shawar SM, Vyas JM, Shen E, et al. Differential amino-terminal anchors for peptide binding to $\mathrm{H}-2 \mathrm{M} 3 \mathrm{a}$ or $\mathrm{H}-2 \mathrm{~Kb}$ and H-2Db. J Immunol 1993;151: 201-210.

58 Vyas JM, Shawar SM, Rodgers JR, et al. Biochemical specificity of H-2M3a. Stereospecificity and spacefilling requirements at position 1 maintain $N$-formyl peptide binding. J Immunol 1992;149:3605-3611.

59 Vyas JM, Rodgers JR, Rich RR. H-2M3a violates the paradigm for major histocompatibility complex class I peptide binding. J Exp Med 1995;181:1817-1825.

60 Wang CR, Castano AR, Peterson PA, et al. Nonclassical binding of formylated peptide in crystal structure of the MHC class Ib molecule H2-M3. Cell 1995;82: 655-664.

61 MacDermott RP. Chemokines in the inflammatory bowel diseases. J Clin Immunol 1999;19:266-272.

62 Graves DT, Jiang Y. Chemokines, a family of chemotactic cytokines. Crit Rev Oral Biol Med 1995;6: 109-118.

63 Smith PD, Smythies LE, Mosteller-Barnum M, et al. Intestinal macrophages lack CD14 and CD89 and consequently are down-regulated for LPS- and IgAmediated activities. J Immunol 2001;167:2651-2656.

64 Smythies LE, Sellers M, Clements RH, et al. Human intestinal macrophages display profound inflammatory anergy despite avid phagocytic and bacteriocidal activity. J Clin Invest 2005;115:66-75.

65 Chamaillard M, Girardin SE, Viala J, et al. Nods, Nalps and Naip: intracellular regulators of bacterialinduced inflammation. Cell Microbiol 2003;5: 581-592.

66 Le Y, Murphy PM, Wang JM. Formyl-peptide receptors revisited. Trends Immunol 2002;23:541-548.

67 Schenk M, Bouchon A, Birrer S, et al. Macrophages expressing triggering receptor expressed on myeloid cells-1 are underrepresented in the human intestine. J Immunol 2005;174:517-524.

68 Charrier L, Driss A, Yan Y, et al. hPepT1 mediates bacterial tripeptide fMLP uptake in human monocytes. Lab Invest 2006, in press.
69 Eckmann L. Innate immunity and mucosal bacterial interactions in the intestine. Curr Opin Gastroenterol 2004;20:82-88.

70 Eckmann L. Sensor molecules in intestinal innate immunity against bacterial infections. Curr Opin Gastroenterol 2006;22:95-101.

71 Philpott DJ, Girardin SE. The role of Toll-like receptors and Nod proteins in bacterial infection. Mol Immunol 2004;41:1099-1108.

$72 \mathrm{Ku}$ CL, Yang K, Bustamante J, et al. Inherited disorders of human Toll-like receptor signaling: immunological implications. Immunol Rev 2005;203: 10-20.

73 Barnich N, Aguirre JE, Reinecker HC, et al. Membrane recruitment of NOD2 in intestinal epithelial cells is essential for nuclear factor-\{kappa\}B activation in muramyl dipeptide recognition. J Cell Biol 2005;170:21-26.

74 Inohara N, Chamaillard M, McDonald C, et al. NODLRR proteins: role in host-microbial interactions and inflammatory disease. Annu Rev Biochem 2005;74: 355-383.

75 Inohara N, Nunez G. NODs: intracellular proteins involved in inflammation and apoptosis. Nat Rev Immunol 2003;3:371-382.

76 Murillo LS, Morre SA, Pena AS. Toll-like receptors and NOD/CARD proteins: pattern recognition receptors are key elements in the regulation of immune response. Drugs Today (Barc) 2003;39:415-438.

77 Strober W, Murray PJ, Kitani A, et al. Signalling pathways and molecular interactions of NOD1 and NOD2. Nat Rev Immunol 2006;6:9-20.

78 Tanabe T, Chamaillard M, Ogura Y, et al. Regulatory regions and critical residues of NOD2 involved in muramyl dipeptide recognition. EMBO J 2004;23: 1587-1597.

79 Viala J, Sansonetti P, Philpott DJ. Nods and 'intracellular’ innate immunity. C R Biol 2004;327:551-555.

80 Hampe J, Frenzel H, Mirza MM, et al. Evidence for a NOD2-independent susceptibility locus for inflammatory bowel disease on chromosome 16p. Proc Natl Acad Sci USA 2002;99:321-326.

81 Hampe J, Cuthbert A, Croucher PJ, et al. Association between insertion mutation in NOD2 gene and Crohn's disease in German and British populations. Lancet 2001;357:1925-1928.

82 Hugot JP, Chamaillard M, Zouali H, et al. Association of NOD2 leucine-rich repeat variants with susceptibility to Crohn's disease. Nature 2001;411:599-603.

83 Lesage S, Zouali H, Cezard JP, et al. CARD15/NOD2 mutational analysis and genotype phenotype correlation in 612 patients with inflammatory bowel disease. Am J Hum Genet 2002;70:845-857.

84 Ogura Y, Bonen DK, Inohara N, et al. A frameshift mutation in NOD2 associated with susceptibility to Crohn's disease. Nature 2001;411:603-606.

85 Gutierrez O, Pipaon C, Inohara N, et al. Induction of Nod2 in myelomonocytic and intestinal epithelial cells via nuclear factor-kappa B activation. J Biol Chem 2002;277:41701-41705.

$86 \mathrm{Oh} \mathrm{HM}$, Lee HJ, Seo GS, et al. Induction and localization of NOD2 protein in human endothelial cells. Cell Immunol 2005;237:37-44.

87 Rosenstiel P, Fantini M, Bräutigam K, et al. TNF- $\alpha$ and IFN $-\gamma$ regulate the expression of the NOD2 (CARD15) gene in human intestinal epithelial cells. Gastroenterology 2003;124:1001-1009. 
88 Anderle P, Nielsen CU, Pinsonneault J, et al. Genetic variants of the human dipeptide transporter PEPT1. J Pharmacol Exp Ther 2006;316:636-646.

89 Bretschneider B, Brandsch M, Neubert R. Intestinal transport of beta-lactam antibiotics: analysis of the affinity at the $\mathrm{H}+$ /peptide symporter (PEPT1), the uptake into Caco-2 cell monolayers and the transepithelial flux. Pharmaceut Res 1999;16: $55-61$.

90 Brodin B, Nielsen CU, Steffansen B, et al. Transport of peptidomimetic drugs by the intestinal Di/tri-peptide transporter, PepT1. Pharmacol Toxicol 2002;90: 285-296.

91 de Vrueh RL, Smith PL, Lee CP. Transport of L-valineacyclovir via the oligopeptide transporter in the human intestinal cell line, Caco-2. J Pharmacol Exp Ther 1998;286:1166-1170.

92 Friedman DI, Amidon GL. Passive and carriermediated intestinal absorption components of two angiotensin converting enzyme (ACE) inhibitor prodrugs in rats: enalapril and fosinopril. Pharmaceut Res 1989;6:1043-1047.

93 Friedman DI, Amidon GL. Intestinal absorption mechanism of dipeptide angiotensin converting enzyme inhibitors of the lysyl-proline type: lisinopril and SQ 29, 852. J Pharm Sci 1989;78:995-998.

94 Jung D, Dorr A. Single-dose pharmacokinetics of valganciclovir in HIV- and CMV-seropositive subjects. J Clin Pharmacol 1999;39:800-804.

95 Kramer W, Girbig F, Gutjahr U, et al. Interaction of renin inhibitors with the intestinal uptake system for oligopeptides and $\beta$-lactam antibiotics. Biochim Biophys Acta 1990;1027:25-30.

96 Nielsen CU, Supuran CT, Scozzafava A, et al. Transport characteristics of L-carnosine and the anticancer derivative 4-toluenesulfonylureido-carnosine in a human epithelial cell line. Pharmaceut Res 2002; 19:1337-1344.

97 Shu HJ, Takeda H, Shinzawa $\mathrm{H}$, et al. Effect of lipopolysaccharide on peptide transporter 1 expression in rat small intestine and its attenuation by dexamethasone. Digestion 2002;65:21-29.

98 Steffansen B, Lepist EI, Taub ME, et al. Stability, metabolism and transport of D-Asp(OBzl)-Ala-a model prodrug with affinity for the oligopeptide transporter. Eur J Pharm Sci 1999;8:67-73.

99 Steffansen B, Nielsen CU, Brodin B, et al. Intestinal solute carriers: an overview of trends and strategies for improving oral drug absorption. Eur J Pharm Sci 2004;21:3-16.

100 Steffansen B, Nielsen CU, Frokjaer S. Delivery aspects of small peptides and substrates for peptide transporters. Eur J Pharm Biopharm 2005;60:241-245.
101 Swaan PW, Stehouwer MC, Tukker JJ. Molecular mechanism for the relative binding affinity to the intestinal peptide carrier. Comparison of three ACE-inhibitors: enalapril, enalaprilat, and lisinopril. Biochim Biophys Acta 1995;1236:31-38.

102 Swaan PW, Tukker JJ. Carrier-mediated transport mechanism of foscarnet (trisodium phosphonoformate hexahydrate) in rat intestinal tissue. J Pharmacol Exp Ther 1995;272:242-247.

103 Terada T, Sawada K, Saito H, et al. Inhibitory effect of novel oral hypoglycemic agent nateglinide (AY4166) on peptide transporters PEPT1 and PEPT2. Eur J Pharmacol 2000;24:11-17.

104 Terada T, Inui K. Peptide transporters: structure, function, regulation and application for drug delivery. Curr Drug Metab 2004;5:85-94.

105 Walter E, Kissel T, Raddatz P. Transport of peptidomimetic renin inhibitors across monolayers of a human intestinal cell line (Caco-2): evidence for self-enhancement of paracellular transport route. Pharmaceut Res 1995;12:1801-1805.

106 Yang CY, Dantzig AH, Pidgeon C. Intestinal peptide transport systems and oral drug availability. Pharmaceut Res 1999;16:1331-1343.

107 Catania A, Cutuli M, Garofalo L, et al. The neuropeptide alpha-MSH in host defense. Ann NY Acad Sci 2000;917:227-331

108 Cutuli M, Cristiani S, Lipton JM, et al. Antimicrobial effects of alpha-MSH peptides. J Leukoc Biol 2000;67:233-239.

109 Getting SJ. Melanocortin peptides and their receptors: new targets for anti-inflammatory therapy. Trends Pharmacol Sci 2002;23:447-449.

110 Getting SJ, Schioth HB, Perretti M. Dissection of the anti-inflammatory effect of the core and C-terminal (KPV) alpha-melanocyte-stimulating hormone peptides. J Pharmacol Exp Ther 2003;306:631-637.

111 Luger TA, Scholzen TE, Brzoska T, et al. New insights into the functions of alpha-MSH and related peptides in the immune system. Ann NY Acad Sci 2003; 994:133-140.

112 Mandrika I, Muceniece R, Wikberg JE. Effects of melanocortin peptides on lipopolysaccharide/interferon-gamma-induced NF-kappaB DNA binding and nitric oxide production in macrophage-like RAW 264.7 cells: evidence for dual mechanisms of action. Biochem Pharmacol 2001;61:613-621.

113 Breese EJ, Michie CA, Nicholls SW, et al. Tumor necrosis factor alpha-producing cells in the intestinal mucosa of children with inflammatory bowel disease. Gastroenterology 1994;106:1455-1466.

114 Sekut L, Connolly K. AntiTNF-alpha agents in the treatment of inflammation. Expert Opin Invest Drugs 1998;7:1825-1839.

Supplementary Information accompanies the paper on the Laboratory Investigation website (http://www. nature.com/labinvest). 